\title{
An Educational Approach to Elementary School Students' Free Time
}

\author{
Jasenka Martinčević \\ Third Elementary School Varaždin
}

\section{Abstract}

The aim of this research was to examine the relationship between sociodemographic characteristics and elementary school students' (grades $5-8$ ) estimates of the importance of particular secondary needs. The sample comprised 196 participants. The starting premise was the concept of "Four wishes" for defining the situation by W. I. Thomas (1863 - 1947). The research instrument used in this research was a specifically designed questionnaire founded on the four wishes by Thomas: the wish for security, wish for response, wish for recognition and wish for new experience. The Mann-Whitney $U$ test, factor analysis, descriptive statistical analysis, linear regression analysis, Kruskal Wallis test and correlation analysis were applied.

The research results show statistically significant differences in the estimate of importance of particular needs with respect to gender, i.e. participants' age. A correlation was established between expressing the importance of the need for security with respect to age, and a positive correlation between recognition and participants' age. Furthermore, a correlation was found between age and expressing the need for new experience among participants. The research established that female participants have a significantly greater need for recognition.

Key words: education for free time: educational approach to free time; students' needs

\section{Introduction}

The $21^{\text {st }}$ century brought about many changes in daily school life. In times with rare strongholds and unquestionable authorities, school is also changing. We live in a time of insecure references, where intangible value foundations are practically non-existent. Values of isolated individuals who are continuously online are dominating, where the virtual environment offers an increasing number of electronic friends. About twenty 
years ago we witnessed the emergence of the Internet which has since become more and more accessible to the greater part of humankind. The World Wide Web or www, the world's web or Internet for short, is the result of work of the military industry, the descendant of ARPANET, a military computer network in the United States of America. Upon moving onto the civil sphere, the system became widely popular around the world in a very short time. In terms of space, messages that emerge from the same place simultaneously spread and influence far beyond the boundaries of traditional "communities of direct contact and state-sanctioned public spheres which at the local level can limit discussions and censor topics under the threat of local sanctions" (Shields, 2001, p. 28). Internet and many other modern-day inventions bring many positive shifts to society, but also many forms of alienation. Long distance interaction without the physical presence has been enabled. One of the negative aspects is the everyday phenomenon of reality being pushed into the background, behind the illusion presented by the media. Little children who "...cannot yet differentiate reality from life presented through media, are gladly immersed into the playful, attractive imagery coming from the television and computer screens" (Košir et al., 1999, p. 27). Daily exposure to media indicates the need of developing media literacy as the ability to critically observe content offered on the media market. Availability of inappropriate content increases the possibility of manipulation of children and youth, and "the most aggressive form of manipulation is present on the Internet. Scenes of brutal violence are ever more frequent, becoming rituals of exciting entertainment" (Miliša et al., 2009, p. 178). Still, despite that, the availability of content plays a great role in establishing a democratic society. British sociologist Antony Gidenns says that we live in a "freed world" and that an era of time that created so many drastic changes in a small period of time has not yet existed (Hainschink \& Stumpner, 2012). Awareness within the generational circle has intensified multifold; in an instant, young people can find out what is going on in a different part of the world. That can be a great advantage of contemporary education permeated with values of interculturalism as the "principle and practice of modern and democratic societies in the sense of mutual understanding, dialogue, respect of the Other and the Foreign, and the skill of living among differences" (Previšić, 1994, p. 19), and presents an important precondition for inhibiting prejudices about foreigners (Held, 1990).

Communication between people in the $21^{\text {st }}$ century demands not only technical requirements which enable being online, as “...communication between people does not depend on the technology but on their psychological motives and situations they find themselves in" (Miljković \& Rijavec, 2002, p. 5). Present-day preschool teachers, more than ever before, have the responsibility to develop in preschoolers "appropriacy, efficiency and flexibility of communicative readiness" (Fisher \& Adams, 1994, p. 222).

Today's world is "fast, complex, dense, and insecure" (Hargreaves, according to Stoll \& Fink, 2000, p. 21). Owing to upbringing as the fundamental category of human existence, man is able to transfer human values. School is an educational institution but 
also a rearing institution. In addition to the compulsory educational activities, school has an important role in students' free time, striving to turn young persons' free time into opportunities for creative production and reflection of the world around us. It is expected that modern schools provide not only educational content but an overall positive environment.

\section{School as a factor of educational shaping of free time}

Each student has his/her characteristics which are determined by genetic inheritance, environmental history of the cultural community they come from and individual volition. Therefore, uniform school situations are received differently by students. One of the factors that has an effect on reception is certainly the influence of upbringing within a particular cultural milieu, as "formation of meaning implies situational meetings with the world in their applied cultural contexts in order to find out what it is about. Although meanings "in the head" are drawn from the culture that creates them" (Bruner, 1996, p. 19).

The growing popularity of the holistic paradigm confronts reducing the human being to only one - rational dimension. Its advocates stress that man is a unique being with a physical dimension as an important dimension of human existence. "The history of pedagogy is the history of the disappearance of the body in pedagogy... and Socrates initiated the turn from physical towards spiritual... while efforts directed towards school reform and education at the onset of the $21^{\text {st }}$ century will not be able to bypass the phenomenon of physicality" (Palekčić, 1999, p. 452).

Although the holistic paradigm of understanding man is being affirmed, the cognitive dimension still takes up the central position in school life. Reason and analytics are desired characteristics in school practice. When speaking of a student, the foreground is taken by the student's ability to think, remember and infer. Despite such trends, we must not forget that man is a biological, physical, emotional being with all of its multifold qualities. The need for movement is a universal human need that is expressed by very young children. As a child in a crib starts to move, it starts to strengthen its body. The first year of life is a very tumultuous period during which a child learns to walk and through movement becomes familiar with the surrounding world. Play is a child's basic activity which is almost always related to movement. This implies running, jumping, jumping to the rhythm of a rhyme etc. The younger the child, the more difficult it becomes to obstruct its movement through social norms. Sitting for long hours in school is therefore not a natural state, so some students help themselves in the acquisition of particular cognitive content by rocking on the chair or by moving school supplies around the desk. However, teachers, mostly due to their lack of information coming from current research results, refer to restless children as undisciplined, disobedient and spiteful.

Many authors point to the importance of man's physical dimension, with particular emphasis on dance as a specific manner of expression through movement. Sounds 
have always encouraged movement as a strong agency for expressing feelings. Some students can best express themselves through movement; therefore, dance should be made part of school curricula parallel to other extracurricular school activities. Methodologically prepared dance is a pedagogical concept that develops various competences. Dance strongly develops awareness of physicality and awareness of one's body, i.e. Körperbewusstsein (Bergman, 2006). Dance helps in developing motor skills and developing sensibility related to particular intellectual operations. Students diagnosed with attention disorders can greatly benefit from professionally led dance. This activity improves concentration and presents an effective exercise in the cognitive domain of student personality. Furthermore, dance helps in the development of selfrespect, in the form of gaining confidence in own abilities which is then transferred to other life activities (Bergmann, 2006). Dance activities that are organized with a group of students, among other things, improve student' social competences. For example, students help each other to remember the choreography and in that way, through dancing, the student shows "...consideration (rücksicht) for others. Additionally, readiness to comply to agreed rules is also developed. After the long and tiring act of sitting in school during regular teaching, dance presents ... a sporting recovery and relaxation and play....which also develops a sense of time, as ...when the child pays attention to various rhythms, it learns to differentiate temporal segments and is able to develop the concept of time" (Bergman, 2016, p. 14). The globally known dancer and dance teacher Rudolf Von Laban (Slovakia 1879 - Great Britain 1958) is author of the work that is intended primarily for dance teachers. This epic work is titled Modern expressive dance in education (Der moderne Ausdrucktanz in der Erziehung). Von Laban's foundation for his dance theory is reduced to four factors of movement: space, strength, time and flow of movement (Bewegungsfluss). The dance method he established has three main points: attention, control and analysis. The development of the mentioned characteristics among students is important for many future life situations. Von Laban stresses that through dance we "immerse in the process of movement action", as opposed to sport, work or similar physical activities where our focus is directed on the practical results of the activity. That means that dance is a movement activity for the sake of movement itself. Therefore, the only aim is to develop expressiveness which becomes an artistic expressionistic dance (Ausdrucktanz). Laban's school of expressionistic dance was continued by his student Mary Wigman (1886 - 1973). As dance does not have a pragmatic function besides the expression of aesthetic essence of beauty, we can associate it with the primary purpose of education and school as a place where learning is coercion free, which is the authentic meaning of the concept skhole. The concept stands for the place for authentic humanistic development within the framework of free time, i.e. according to some authors pure leisure, which, in this context, bears an entirely positive connotation. "While free time is the time during which a person is free of work or labor as a compulsory activity, leisure is the time 
during which a person is free for direct realization of work, for play, creativity..." (Polić, 2005, p. 35).

Music has always been an important part of man through which broad spectra of emotional states could be expressed; from great joy to deep sadness. Today, high technological developments brought about great possibilities for reproducing music through broadly available media, increasing the possibility of following directions in music. Youth often identify with popular musicians by becoming fans. In addition to going to concerts, which is often unattainable, young people follow trends through the possibilities the Internet offers. Numerous television shows or internet activities enable direct contacts with popular musicians (Stars zum Anfassen, Heyer \& Palentien, 2013, p. 77), or even opportunities for young persons to show their talents. Affiliation to a certain music scene can be a way of identifying with a particular group, which young people certainly need at that age. That can also be a way of avoiding lack of understanding by the social environment they live in. In addition to listening to a certain type of music, some of them create their own music pieces which today they can easily present to the broader public, owing to services such as YouTube or Facebook. All of this is realized not only through the sound displays, but by creating various visual materials, mostly music videos. In that way they can increase interest, intrigue the music scene for personal music creativity. Playing music and singing in such informal groups offers valuable creative experience and develops social and cooperative learning. The new paradigm of fast interchangeability comes to surface in this segment as the high ability to present their media offers is the source of fast-moving popularity (schnellebig) (Heyer \& Palentien, 2013). Educational design of primary students' free time should take into consideration the possibilities offered by new technological achievements and offer students the possibility to use them on a daily basis.

Regardless of the form of realization, art takes up an important part in the overall wellbeing of humankind. Only a fragment of the population carries the creative potential and a particular sensibility for creative expression. In order to develop that potential, in addition to the innate gift, other conditions must be ensured. As a start, it is necessary to recognize a particular talent and then patiently and continuously provide conditions for its promotion. Activities that develop such potential are defined by the so called "subjective factors (social status of youth and their parents, education, abilities, acquired habits), and so called objective factors (cultural heritage from the narrow and broad environment, current offer and availability of particular content and similar)" (Ilišin, 2008, p. 271). The possibility of expressiveness through art is available to only a small part of the population. Art is not given to all people in the same way. Artists are persons of particularly high sensibility and a great gift of expressiveness. However, interest for the arts is not limited to its creators; rather it is an occurrence that strongly touches the emotional dimension of nearly every person with its uniqueness and great spiritual strength. Only human beings recognize art which is proof that art is part of our humane and cultural world. Therefore, art should 
be made available to the majority of humankind. It is important to stress that through daily focus of education in the direction of the humanities, this idea can be realized for the majority part in school within the aesthetic framework of education. The area of such educational influence should not be limited to extracurricular activities within the school curriculum. It should extend to the entire educational practice of a school institution and transfer out of the institutional framework as a source for developing humanism in the broadest sense. Relief from emotional tension can be realized by activities in all forms of art to which established artists could contribute significantly. In that way their contribution would not be in the aesthetic dimension of the world around them, but in the development of communication with younger generations. Here we mention Uta Reeh's initiative, described in the book "Schulkunst - Kunst verändert Schule”. It describes a strong engagement of artists in developing such initiatives in the "Dieter-Forte - Gesamtschule" school in Düsseldorf, Germany. Author Reeh accentuates that "... school art means networking or artistic thought and school culture" and the mentioned initiative should permanently be interwoven into the essence of school, “... which is opposite to isolated external projects" (Reeh, 2008, p. 13). Students should feel the school environment as their emotional area that they can freely access in a creative way. The organization of school, from classrooms, dining rooms, halls, even sport halls, under the guidance of an artist can turn into notable creative projects where young people are allowed to take initiative and consequently take responsibility for the outcomes of their ideas. Young people are entrusted with the change of their living space which can become an important factor for improving the emotional health of students. Such treatment by teachers and school management sends students the message that they are trusted and contributes to building intergenerational understanding. It is also important that the realization of interventions into school space involves students of different age in order to improve cooperative learning, empathy at all levels and aspiration towards mutually agreed goals. The realization of that idea and its continuous development requires "understanding and support of school management and colleagues in order to work parallel with rigid school structures..." (Reeh, 2008, p. 12). School is a place where educational work is realized. However, school is also an institution where complex policy of a particular state community is applied. Therefore, continuous balance of the emotional and rational is necessary, i.e. support for the creative and positive unrestrained youth spirit on the one side, and administrative policies that frequently seem as obstacles to creativity on the other side of daily educational work.

Despite numerous scientific evidence that speak in favor of increasing attention to the physical and emotional segment of a student's personality, school practice, under the pretext of insufficient time due to extensive curricula, unduly place elementary human physicality and emotion into the background. The mentioned situations lead to discontent, feeling of unfulfillment which can result in insecurity, even neuroticism among students. The mentioned unfavorable school environment does not contribute 
to improving the quality of school's educational work as "without respecting the inner experience and by emphasizing the external world, objective knowledge, information that has to be acquired, remembered, reproduced we overemphasize the rational sphere of personality and neglect feelings, attitudes and values thus diminishing the educational process" (Bratanić, 2002, p. 61).

Leisure time is a specific area of an individual's freedom which contains great potential for creative development. It is an area that creates foundations for developing particular values that can be positive, humane and constructive. However, in an area that is not formed, defined nor occupied, unfavorable value aspirations can prevail. For a young, sensitive person, leisure time is by nature preordained for unrestrained, unstructured thought, but also concrete actions. Such space is reserved for various experiments which can be very useful as practicing grounds for a young person. Testing and moving limits, as an important segment of maturation, contributes to any learning, particularly for learning social skills. Therefore, a student must be offered possibilities for independent decision-making as a valuable part of the process of maturation. This process should take place in a positive environment as "it is evident that children must dare, must be set free, but should not fall into the hands of those who seek them" (Flitner, 2005, p. 81). We are faced with the problem of various forms of socially unacceptable behaviors; therefore, schools create and carry out many preventive programs in order to contribute to strengthening self-awareness, selfconfidence and self-respect (Jull, 2001), and for young people to accept themselves and their own qualities. Students should learn to listen to each other, develop empathy, communicate and create new values. If this could be only partially realized, it would lead to the reduction of the frequent occurrence of boredom among children. At first sight, this seems unusual as we are aware of the fact that students are burdened with daily schedule of duties. Immediately after their school duties they move on to their extracurricular activities and by the end of the week they are overcome by boredom which is related to the inability to organize and design their free time. Students are frequently incapable of planning their free time without the influence of external encouragement in the form of professional animators, and yet their free time is their only space of personal freedom. If we do not support them in developing their own ideas "...unless they learn to create their own world, they will only be able to create and use things in the way others determine" (Polić, 2005, p. 43). The present-day has a lot to offer. There is ample content, but from the vast multitude one has to know how to select quality and quantity of particular content, i.e., acquire the skill of relaxation. One should know how to do nothing but imagine, daydream, or contemplate. This kind of artistry is described in an Indian tribal custom: “... he who doesn't want to communicate with others should simply turn to the rock and no one will bother. In a similar way, we could be freed from commonplace conversations about the weather that people lead just because they think they have to talk" (Makarovič, 1972, p. 87). Man is a social being and a long time ago Aristotle emphasized man's nature with the 
known term Zoon politikon. Thus, our student, in addition to the ability of plunging and becoming acquainted with himself, should be able to live in a community with others. In order to survive in evermore-complex social conditions, man simply must be referred to the people in the surroundings and be ready for interpersonal help and support. Developing the culture of teamwork is imperative for present-day living. Technological complexity surpasses the possibilities and brevity of the individual's life span. Free time can be the opportunity for common, pleasant company where the various students' needs can be fulfilled.

One of the basic needs is the need for movement that has been systematically neglected over a long period of time. There are plenty of excuses with the most frequent being lack of time. This basic need can be realized in various ways, from organizing sport activities, dance as a very sophisticated activity, to very simple non-structured inquisitive walks by a group of peers where social skills and culture of teamwork in the broadest sense can also be developed. Each school develops in the desired direction which has to be defined by the school's development policies. For instance, one of the priorities that can be defined is to develop students' teamwork skills. A measure which can realize a strategic goal defined as such can be to establish extracurricular activities or plan various activities throughout the school year which can contribute to realizing this goal. This implies organizing hiking groups, dance groups or young biologists or ecologists groups that systematically observe the development of a particular biological occurrence through teamwork, young technicians who work on the development of a particular technical solution, young information scientists who work on developing new programs which will solve a particular task and other. For developing the culture of teamwork in school conditions, extracurricular activities hold a special place. They have a more relaxed atmosphere, in comparison to teaching, as "school anxiety is always reduced to or correlated with fear of testing or grading" (Matijević, 2004, p. 31). Here, the teacher is more of a coordinator who helps the team develop. Assessment can be carried out through note-taking into a form devised for observation, e.g. "patiently and skillfully helps others, helps the group by giving ideas and suggestions, can listen and accept others, skillfully mediates if conflict or similar occurs" (Klipert, 2001, p. 62).

\section{Methodology}

\section{Aim}

The theoretical starting point for this research was Thomas's concept of four wishes for defining the situation. W. I. Thomas $(1863$ - 1947) is a representative of the Chicago school. His best-known work "The Polish Peasant in Europe and America" represents a turning point in the methodology of social sciences. Thomas's basic thought that determined further developments in the social sciences research methodology is known as the phrase "If people define the situation as realistic, it will be realistic in its consequences" (as cited in Ritzer, 1997, p. 48). Experiencing the external world depends 
on an individual person, which means that a particular situation can be emotionally and cognitively strongly defined for one person and leave no impression on another person who does not even observe the situation. What is happening within a human being, i.e. what matches the reception of a particular external reality actually determines an individual's behavior to a certain external stimulus. The manner in which a certain situation is received is not defined only by the present behavior of an individual but becomes an important factor for future reception of the external world. Thomas holds that a person experiences the surrounding world in his or her own particular way and behaves in accordance with the experience of reality according to the four basic wishes. According to Thomas's concept, those are the following: the wish for new experience, wish for security, wish for response, and wish for recognition.

The aim is to explore how primary school students assess the importance of meeting the need for new experiences, for safety, for response and for recognition. The analysis of the results could become the basic principle for creating educational free time for elementary school students. A student could indirectly become an active participant in conceptualizing leisure time activities, i.e. the subject in the educational process. In order to provide conditions in which the school would become the central part of creative meetings (Bratanić, 1993) of students and teachers, it is necessary to establish good communication and explore students' basic interests. The starting point of this empirical research was Thomas's theoretical construct of four wishes for defining the situation which served in the operationalization of elementary school students' needs.

The following hypotheses were set:

- There is no statistically significant difference in the estimate of Thomas's concept of four wishes for defining the situation with respect to participants' gender.

- There is no statistically significant difference in the estimate of Thomas's concept of four wishes for defining the situation with respect to participants' grade.

- There is no statistically significant difference in the selection of four most desired free-time activities with respect to participants' grade.

- There is no statistically significant difference in the selection of four most desired free-time activities with respect to participants' gender.

\section{Sample}

The respondents in this study were students $(\mathrm{N}=196)$ of two Varaždin elementary schools: $2^{\text {nd }}$ elementary school in Varaždin and $3^{\text {rd }}$ elementary school in Varaždin. The $2^{\text {nd }}$ elementary school is located near the town center, and $3^{\text {rd }}$ elementary school is located at the southern part of the city. Part of $3^{\text {rd }}$ elementary school's district is a suburban neighborhood, so one quarter of students come to school by school bus. Annually, about 800 students enroll in $2^{\text {nd }}$ elementary school, while $3^{\text {rd }}$ elementary school is attended by 400 students. The sample included $5^{\text {th }}$ to $8^{\text {th }}$ grade students. 92 (47\%) male students and 104 (53\%) female students participated in the study. There were 65 fifth grade students, 40 sixth grade students, 50 seventh grade students and 41 eighth 
grade students considering the class they attend. The detailed gender structure of the respondents was as follows: out of a total of 65 fifth-grade students, 29 (45\%) were male and 36 (55\%) were female. As for the respondents attending the sixth grade, 17 (43\%) were male and 23 (58 \%) were female. 50 seventh grade students participated in the study, of which 26 (52\%) were male and 24 female (48\%). Out of the total of 41 respondents - eighth grade students who participated in the survey, there were 20 male students (49\%) and 21 female students (51\%).

Table 1

General student statistics

\begin{tabular}{cccc}
\hline grade & boys & girls & Total \\
\hline $5^{\text {th }}$ & $29(44.62 \%)$ & $36(55.38 \%)$ & $65(33.16 \%)$ \\
$6^{\text {th }}$ & $17(42.50 \%)$ & $23(57.50 \%)$ & $40(20.41 \%)$ \\
$7^{\text {th }}$ & $26(52.00 \%)$ & $24(48.00 \%)$ & $50(25.51 \%)$ \\
$8^{\text {th }}$ & $20(48,78 \%)$ & $21(51.22 \%)$ & $41(20.92 \%)$ \\
Total & $92(46.94 \%)$ & $104(53.06 \%)$ & $196(100 \%)$ \\
\hline
\end{tabular}

\section{Instrument}

For the purpose of the research, the survey method was applied using a specifically designed questionnaire as the research instrument. In the introductory part of the survey questionnaire, the survey was briefly presented to the respondents, asking for honesty in answering the questions. It was stated that the survey is anonymous and that it is important to answer all the questions. This was followed by questions related to the demographic characteristics of the respondents: gender and class they attend.

The first part of the questionnaire contained sixteen statements, which the respondents needed to evaluate with a five-point rating scale, with 1 indicating that they did not agree with the statement at all, while 5 meant that they completely agreed with the statement. The respondents were given detailed instructions on how to complete this part of the questionnaire. They were offered sixteen statements describing four of Thomas' desires for defining the situation. Factor analysis extracted four factors that fit the Thomas concept.

F1 - Wish for security was represented with the following statements: (12) I've met my best friends in school; (15) I think that our school is one of the best schools; (9) I have friends in school which I can confide in; (16) I'm proud to be a student of our school; (7) Extracurricular activities offered in our school entirely meet my needs.

F2 - Wish for response was represented with the following statements: (14) I think that the results of our work should frequently be seen by our parents, friends and others; (11) We should help each other more; (6) I'm happiest with my old friends.

F3 - Wish for recognition is represented with the following statements: (2) Going on field trips into the unknown is the best; (5) I think that being home is best after all (a negative correlation was established); (10) I think that we don't have enough time in school for conversations with friends; (13) If I were the best athlete in the school, I think that everyone would have to know that. 
F4 - Wish for new experience is represented with the following statements: (8) I don't like surprises, neither pleasant nor unpleasant (a negative correlation value was established); (1) I'd like to meet new friends; (3) I'd like to find my way in a new environment; (4) I'd like to try something entirely new, for example parachuting.

\section{Table 2}

Factor Analysis - Rotated Component Matrix: Principal Component Analysis Extraction Method and Varimax with Kaiser Normalization Rotation Method

\begin{tabular}{ccccc}
\hline & \multicolumn{4}{c}{ Component (Factor) } \\
\cline { 2 - 4 } Question & $\begin{array}{c}\text { F1 } \\
\text { Wish for security }\end{array}$ & $\begin{array}{c}\text { F2 } \\
\text { Wish for response }\end{array}$ & $\begin{array}{c}\text { F3 } \\
\text { Wish for recognition }\end{array}$ & $\begin{array}{c}\text { F4 } \\
\text { Wish for new } \\
\text { experience }\end{array}$ \\
\hline 12 & 0.715 & 0.070 & 0.072 & -0.050 \\
15 & 0.640 & 0.147 & -0.232 & 0.306 \\
9 & 0.639 & -0.165 & 0.164 & -0.151 \\
16 & 0.494 & 0.199 & -0.368 & 0.334 \\
7 & 0.448 & 0.422 & -0.168 & 0.030 \\
14 & 0.061 & 0.691 & 0.035 & 0.101 \\
11 & -0.034 & 0.628 & 0.097 & -0.042 \\
6 & 0.300 & 0.404 & -0.045 & -0.208 \\
\hline 2 & 0.266 & 0.038 & 0.611 & 0.066 \\
5 & 0.117 & 0.311 & -0.520 & 0.186 \\
10 & -0.039 & 0.091 & 0.498 & 0.188 \\
13 & -0.193 & 0.308 & 0.459 & -0.036 \\
\hline 8 & -0.134 & 0.193 & 0.025 & -0.580 \\
1 & -0.011 & 0.249 & -0.062 & 0.574 \\
3 & -0.067 & -0.024 & 0.138 & 0.521 \\
4 & -0.029 & -0.061 & 0.457 & 0.488 \\
\hline
\end{tabular}

Table 3

Factor Analysis - KMO and Bartlett's Test

\begin{tabular}{llr}
\hline Kaiser-Meyer-Olkin Measure of Sampling Adequacy. & 0.59 \\
Bartlett's Test of Sphericity & Approx. Chi-Square & 347.44 \\
& df & 120 \\
& Sig. & 0.00 \\
\hline
\end{tabular}

Table 4

Correlations between certain factors

\begin{tabular}{lcccc}
\hline & Security & Response & Recognition & Experience \\
Security & 1.00 & 0.02 & 0.03 & 0.04 \\
Response & 0.02 & 1.00 & 0.00 & -0.07 \\
Recognition & 0.03 & 0.00 & 1.00 & 0.01 \\
Experience & 0.04 & -0.07 & 0.01 & 1.00 \\
\hline
\end{tabular}

The Kaiser-Meyer-Olkin (KMO) index is greater than 0.5, which is the limit of acceptance of a sample for factor analysis, and the same is also shown by Bartlett's 
statistical significance test (Sig.) which is significantly less than 0.05 , therefore, application of factor analysis is justified. Likewise, the correlation between the individual factors is very small, which further shows us that the individual factors did indeed include questions that are very compactly interconnected. This is another indication of the applicability of Thomas' concept of four desires.

The second part of the questionnaire offered fifteen types of extracurricular activities from which the participants were asked to select four as the most attractive. The following activities were listed: (a) rollerblading on the school playground; (b) hiking - going on hiking trips; (c) dance; (d) folk dancing; (e) listening to music - daydreaming; (f) drawing; (g) meetings with artists; (h) making dolls; (i) swimming; (j) modelling making objects from clay and similar materials; $(\mathrm{k})$ organizing and carrying out relief work; (l) playing various games agreed with the leader - from pantomime to dodgeball; (m) various sports meetings - e.g. grade-level competitions in various sports; (n) participation in competitions related to individual public performances, e.g. singing, reciting, telling jokes, etc.; (o) setting up exhibitions of student work (selection and setting up work on display boards). At the end, students had the opportunity to (p) add an activity they like but is not on the list of free-time activities.

\section{Results}

After the research we have come up with results that can more closely describe the aspirations of upper elementary school students. Respondents evaluated sixteen claims using a five-point Likert-type scale. The claims related to different aspects of observing school life, but also to life aspirations in general. For example, several claims described different perceptions of making and maintaining friendships at school. Almost all respondents rated the quality of school friendships as very positive. The statement that read: (9) "I have friends in school which I can confide in" was rated on a 5-point scale with an average score of 4.32; and the statement (12) "I've met my best friends in school" with an average score of 4.25. Respondents generally value the overall school experience with a high grade, which can be substantiated by the medium grade of the statements that read: (16) "I'm proud to be a student of our school" (average grade is 4.57); (15) "I think that our school is one of the best schools" (average rating is 4.03). Respondents are aware of the need for mutual assistance and solidarity among students. Therefore, the statement (11) "We should help each other more" is estimated by a very high mean score of 4.76 . The results of the evaluation of the sixteen claims are presented in Table 5.

Note. Questions: 1) I'd like to meet new friends; 2) Going on field trips into the unknown is the best; 3) I'd like to find my way in a new environment; 4) I'd like to try something entirely new, for example parachuting; 5) I think that being home is best after all; 6) I'm happiest with my old friends; 7) Extracurricular activities offered in our school entirely meet my needs; 8) I don't like surprises, neither pleasant nor unpleasant; 9) I have friends in school which I can confide in; 10) I think that we don't 
have enough time in school for conversations with friends; 11) We should help each other more; 12) I've met my best friends in school; 13) If I were the best athlete in the school, I think that everyone would have to know that; 14) I think that the results of our work should frequently be seen by our parents, friends and others; 15) I think that our school is one of the best schools; 16) I'm proud to be a student of our school. Table 5

General statistical data of evaluating claims according to the Thomas's concept

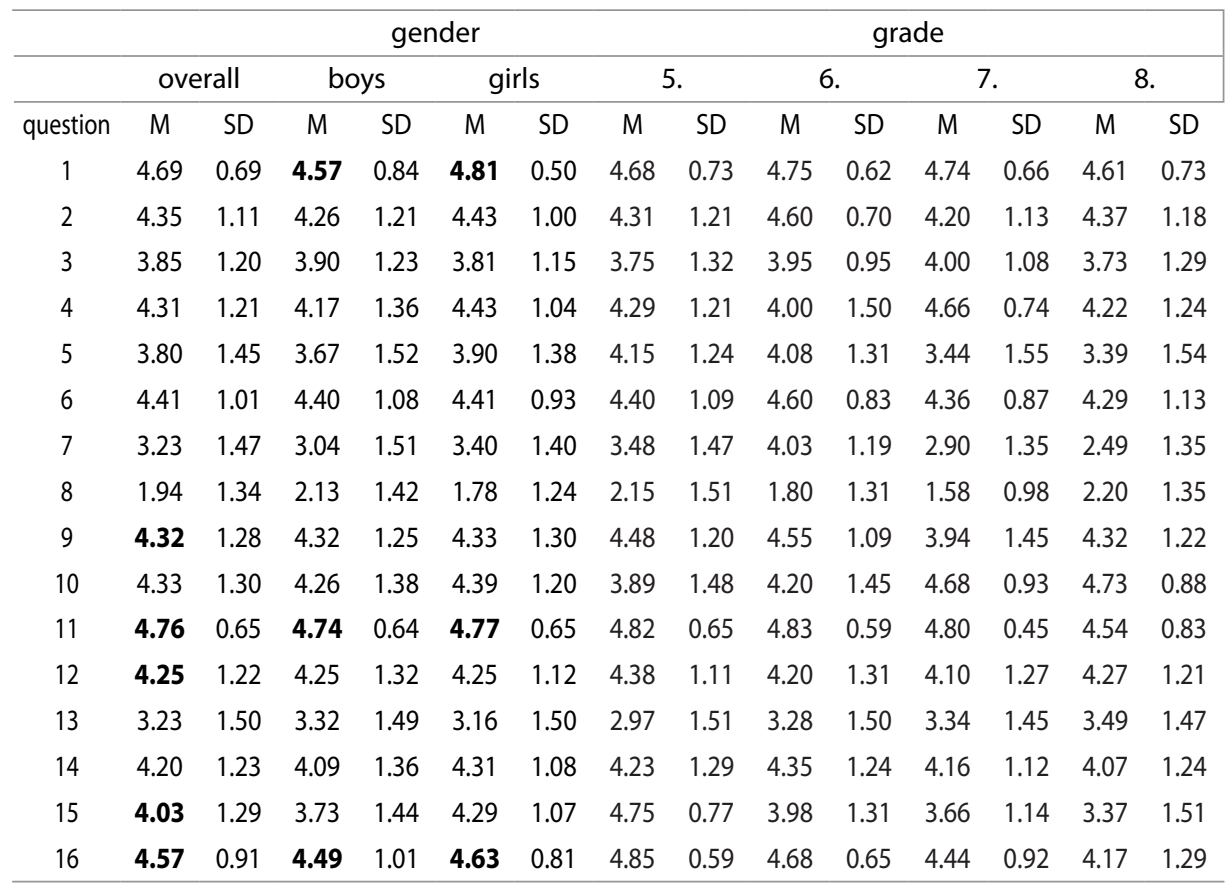

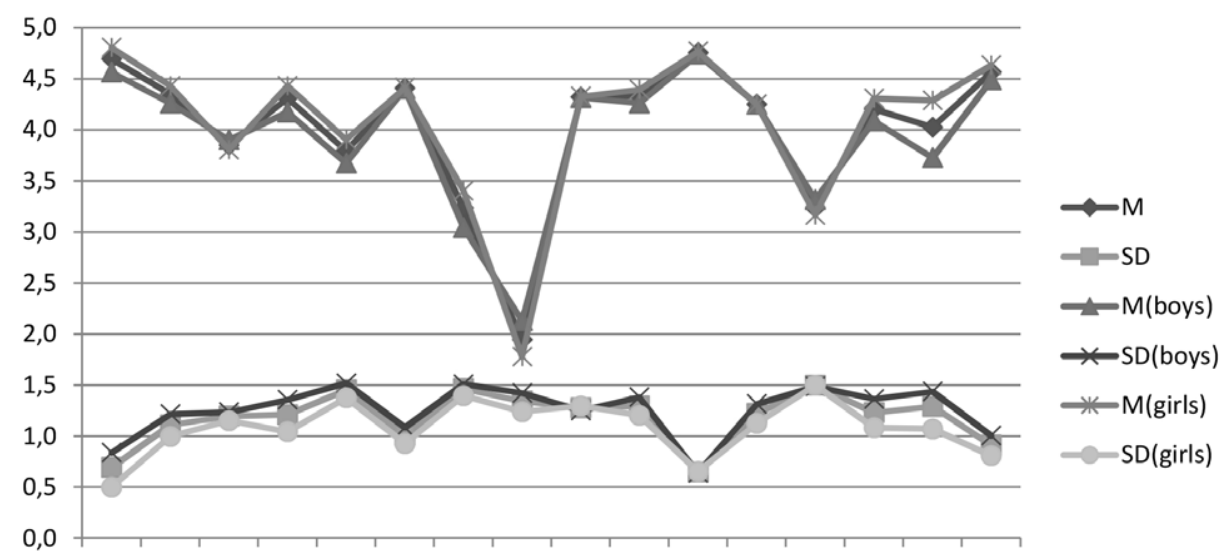

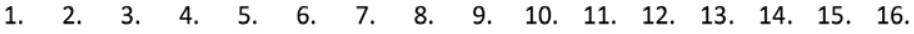
Questions

Figure 1. General statistical data for questions $1-16$ 
Questions (1) I'd like to meet new friends and (11) We should help each other more have the lowest standard deviation, lowest standard deviation of the average, around 0.6, and they are more uniform than other questions. Next are questions (6) I'm happiest with my old friends and (16) I'm proud to be a student of our school with values around 1, while on the other hand questions (5) I think that being home is the best after all, (7) Extracurricular activities offered in our school entirely meet my needs and (13) If I were the best athlete in the school, I think that everyone would have to know that have the greatest deviation, around 1.5 and most diverse answers. Other questions have relatively equal deviations.

Mean values for answers to question (8) I don't like surprises, neither pleasant nor unpleasant (the value around answer 2-I don't agree) and (13) If I were the best athlete in the school, I think that everyone would have to know about that (value around answer 3-undecided) significantly differ from the mean values of answers to other questions that fall around the answers 4 (I agree) and 5 (I agree entirely).

An analysis of sixteen statements describing four of Thomas' desires for defining a situation revealed that within sixteen questions the most uniform results were obtained by the results of two statements, which we conclude on the basis of low standard deviation value. These two statements were similarly estimated by participants regardless of gender. Statements (1) I'd like to meet new friends and (11) We should help each other more are statements for which the arithmetic mean is very high, 4.81 for girls and 4.57 for boys, which means that the majority of participants entirely agreed with the statements. The mentioned speaks in favor of the strong influence education has on youth, which is particularly evident in their estimate of the statement on helping each other. What is more, students are open for new experiences and for meeting new persons. This can be an encouraging finding that is proof of openness toward others. At the same time, students show a high degree of identification with their school regardless of their gender. The mean value for boys is 4.49 and 4.63 for girls. The mentioned can be interpreted as a reflection of a very positive sign regarding the school environment in which students feel comfortable and safe.

By Mann-Whitney's U test (Table 6) we found that in most cases there was no statistically significant difference in the estimation of the stated claims, which is also evident graphically from Figure 1. However, this is not so in the evaluation of the statement that reads (1) I'd like to meet new friends ( $\mathrm{p}=1.7 \%)$. Boys evaluate (Table 5) the desire to meet new friends with a mean score of 4.57 , while girls rate this desire with a grade of 4.81. A statistically significant difference was found with respect to the gender of the respondents (Table 6) and in the evaluation of the claim under number 15 ( $\mathrm{p}=0.3 \%$ ), which refers to the assessment of the school as one of the best. Boys rate their school (Table 5) with a lower mean, 3.73, compared to girls who have a more positive opinion of the school they attend, which is also indicated by a higher grade, 4.29. The school seems to be an institution designed to be more accessible to girls than boys. It has been noted that there is no difference in the mean values according to 
gender when evaluating a statement that reads (12) I've met my best friends in school. This means that all students, regardless of gender at school, really make friends, and consequently develop social competencies.

\begin{tabular}{|c|c|}
\hline Question & Sig. (2-sided test) \\
\hline 1 & 0.017 \\
\hline 2 & 0.544 \\
\hline 3 & 0.375 \\
\hline 4 & 0.228 \\
\hline 5 & 0.344 \\
\hline 6 & 0.629 \\
\hline 7 & 0.105 \\
\hline 8 & 0.075 \\
\hline 9 & 0.700 \\
\hline 10 & 0.628 \\
\hline 11 & 0.482 \\
\hline 12 & 0.430 \\
\hline 13 & 0.454 \\
\hline 14 & 0.460 \\
\hline 1 & 0.003 \\
\hline 16 & 0.366 \\
\hline
\end{tabular}

Table 7

Kruskal Wallis Test Statistics

\begin{tabular}{llcccc}
\hline & & Security & Response & Recognition & Experience \\
\hline \multirow{2}{*}{ Asymp. Sig. } & gender & 0.065 & 0.326 & 0.900 & $\mathbf{0 . 0 1 5}$ \\
& grade & $\mathbf{0 . 0 0 1}$ & 0.161 & $\mathbf{0 . 0 0 0}$ & $\mathbf{0 . 0 3 7}$ \\
\hline
\end{tabular}

Table 8

Regression correlation coefficients between particular factors with respect to participants' gender and age

\begin{tabular}{lcccc}
\hline & Security & Response & Recognition & Experience \\
\hline gender & 0.10 & 0.08 & 0.02 & 0.20 \\
grade & $\mathbf{- 0 . 2 8}$ & -0.14 & $\mathbf{0 . 2 8}$ & -0.05 \\
\hline
\end{tabular}

Table 7 shows that there is a statistically significant difference in the assessment of the factor Wish for New Experience according to the students' gender ( $\mathrm{p}=1.5 \% ;<5 \%)$. There was also a statistically significant difference in the assessment of the Wish for Security $(\mathrm{p}=0.1 \% !)$, Wish for Recognition ( $\mathrm{p}=0 \%$ !) and Wish for New Experience $(\mathrm{p}=3.7 \%)$ factors according to the class the participants attend. Additionally, as seen from Table 8 , a small negative correlation was found $(\mathrm{r}=-0.29)$ in expressing the need for safety in the participants with respect to the class they attend. The older the students, the less attention they give to the factor that describes the need for security according to Thomas's concept. This result is not surprising as students are more open to investigating 
their environment and become more independent as they move into higher grades. This result proves it empirically. Contrary empirical indicators were obtained through the analysis of the factor that expresses participants' needs for recognition. A small, but positive correlation ( $\mathrm{r}=0.28$ ) was established between the need for recognition and participants' grade. The older the students, the stronger the expression of their need for recognition.

In the second part of the questionnaire, participants expressed their preferences for extracurricular activities. Of the seven extracurricular activities offered, four favorites were to be chosen, to which they would like to devote their spare time. Participants were instructed to choose four types of extracurricular activities that they would be happy to attend, even if it was not a school day, e.g. Saturdays.

As can be seen from Table 9, boys in grades $5-8$ are most attracted to the activity called "Various sports' meetings - e.g. grade-level competitions in various sports", while girls from grades $5-8$ are most attracted to the activity of "Rollerblading in the school playground". Fifth- and sixth-grade students' favorite activity is called "Hiking - going on hiking trips". Seventh- and eighth-grade students usually choose a free activity called "Various sports' meetings - e.g. grade-level competitions in various sports".

Table 9

Order of the four most attractive activities

\begin{tabular}{cccccccccccccccc}
\hline & \multicolumn{4}{c}{ boys } & \multicolumn{2}{c}{ girls } & \multicolumn{2}{c}{ gr. 5 } & \multicolumn{2}{c}{ gr.6 } & \multicolumn{2}{c}{ gr. 7} & \multicolumn{2}{c}{ gr. 8 } & \multicolumn{2}{c}{ Total } \\
\hline I. & M & 69 & A & 53 & b & 39 & b & 24 & m & 31 & m & 23 & M & 105 \\
II. & B & 52 & B & 45 & m & 36 & a & 17 & a & 28 & i & 21 & B & 97 \\
III. & I & 48 & C & 40 & a & 25 & i & 17 & b & 23 & p & 21 & A & 86 \\
IV. & P & 37 & P & 38 & p & 23 & I & 16 & i & 22 & e & 20 & I & 82 \\
\hline
\end{tabular}

Note. Activities: a) Rollerblading in the school playground; b) Hiking - going on hiking trips; c) Dance; e) Listening to music - daydreaming; i) Swimming; l) Playing various games in agreement with the leader - from pantomime to dodgeball; $m$ ) Various sports' meetings - e.g. grade-level competitions in various sports; $p$ ) Other activities that you find attractive but are not listed.

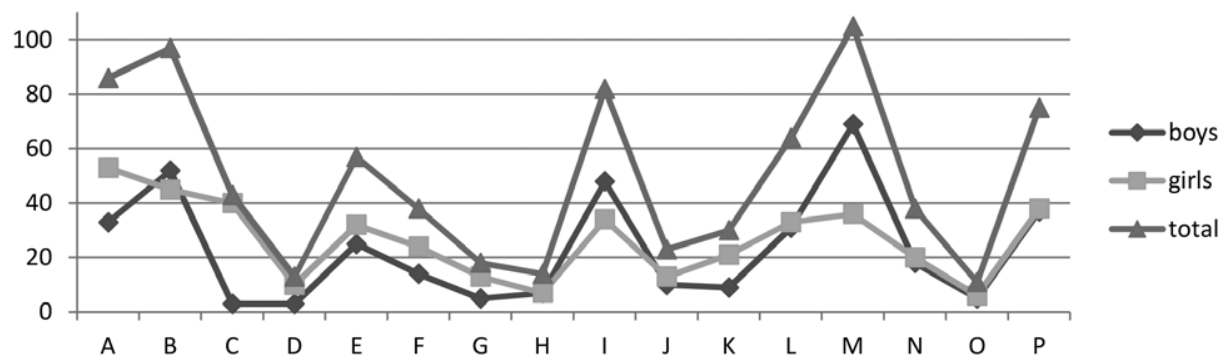

Figure 2. Response frequencies by extracurricular activity choices for boys, girls and in total 


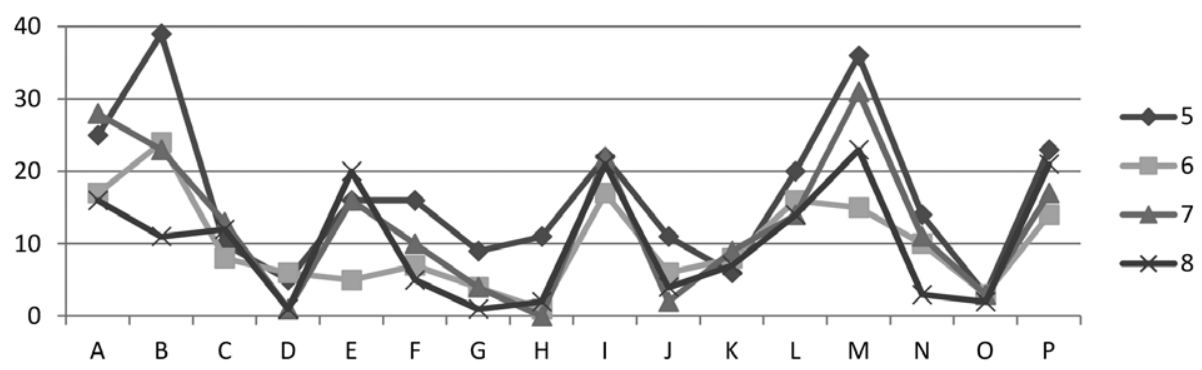

Figure 3. Response frequencies by extracurricular activity choices, grades 5 to 8

\section{Discussion and Conclusion}

This research showed that students experience school life. We became knowledgeable of the direction in which the school curriculum should develop in order to offer students the education for independent conceptualization of free time as an important phenomenon of contemporary society. Generally, the results show that girls feel better than boys in the existing educational system. The participants state that they miss physical activities, play, competitions and entertainment. Therefore, the conceptualization of free time in a school institution should be moving in that direction.

The social environment influences not only the change of students' behavior but how they perceive their environment, how they process it and create their inner spiritual world. The educational factors certainly define, to an extent, students' aspirations. In order to get to know our students, we need to talk about their perception of happiness in the broadest sense of that concept, i.e. find out what they want to achieve in their life at the present time, moment. The concept of education for some distant, future times is not current as students are present here and now, and they are ready to change living conditions together with adults. They are open to accept our educational influence as a relevant factor, i.e. take us into consideration as the "significant others" (Mead, 2003) from which they can learn something regardless of the availability of information. Each person is different by nature; therefore, the results of this research show that a group of participants prefers security and nurturing sense of their home. This group of participants does not like surprises, unknown situations, nor changes in the broadest sense. On the other hand, there are participants who are interested in new experiences and continuously seek new adventures. What are our participants like and what they want to achieve and why were questions to which we were able to give partial answers with this research. In order to establish and strengthen intergenerational solidarity, it is necessary to show a clear intention, initiative and readiness and ability to know the participants' "reference framework". The absence of readiness to communicate leads to a state without communication that we aspire to and therefore the generation gap will become more expressed. The organization of students' free time in school should certainly take into consideration their interests and wishes, as that is the area of free choice where a student's free will should be respected. 


\section{References}

Bergmann, B. (2006). Lernen durch Tanzen. Ein körperorientierter Lernansatz für Kinder nach Montessori. Beltz Verlag.

Bratanić, M. (1993). Međuljudski odnosi nastavnika i učenika. In B. Drandić (Ed.), Priručnik za ravnatelje (pp. 73 - 83 ). Znamen.

Bratanić, M. (2002). Paradoks odgoja. Hrvatska sveučilišna naklada.

Bruner, J. (1996). Kultura obrazovanja. Educa.

Fischer, B. A., \& Adams, L. K. (1994). An introduction to interpersonal communication as relationship. In A. Fischer (Ed.), Interpersonal Communication. Pragmatics of Human Relationships (pp. 3-21). International Editions: McGraw-Hill.

Flitner, A. (2005). Konrade, tako je govorila gospođa mama. Educa.

Hainschink, V., \& Stumpner, S. (2012). Pädagoginnenbildung im spannungsfeld zwischen selbstbestimmung und fremdorientirung - subjekt versus struktur. Erziehung und Unterricht. Österreichische Pädagogische Zeitschrift, 7-8, 620-629.

Held, D. (1990). Modeli demokracije. Školska knjiga.

Heyer, R., \& Palentian, C. (2013). Jugend und musik. Die bedeutung der musik für die persönlichkeitsentwicklung. Pädagogik, 7-8, 76-79.

Ilišin, V. (2008). Interesi i slobodno vrijeme mladih. In V. Ilišin, \& F. Radin (Eds.), Mladi uoči trećeg milenija (pp. 269-298). Državni zavod za zaštitu obitelji, materinstva i mladeži.

Jull, J. (2001). Vaše kompetentno dijete. Educa.

Klipert, H. (2001). Kako uspješno učiti u timu. Zbirka praktičnih primjera.: Educa.

Košir, M., Zgrabljić, N., \& Ranfl, R. (1999). Život s medijima. Doron.

Makarovič, J. (1972). Neke društvene vrednote i razvoj stvaralaštva. In J. Makarovič (Ed.), Kreativnost mladih i slobodno vrijeme (pp. 78-93). Centar za vanškolski odgoj Saveza društava „Naša djeca“ SR Hrvatske.

Matijević, M. (2004). Ocjenjivanje u osnovnoj školi. Tipex.

Mead, G. H. (2003). Um, osoba i društvo. Naklada Jesenski i Turk, Hrvatsko sociološko društvo.

Miliša, Z., Tolić, M., \& Vertovšek, N. (2009). Mediji i mladi. Prevencija ovisnosti o medijskoj manipulaciji. Sveučilišna knjižara.

Miljković, D., \& Rijavec, M. (2002). Komuniciranje u organizaciji. IEP-D2 VERN.

Palekčić, M. (1999). K tematizaciji tjelesnosti u pedagogiji. Paradigma za treće tisućljeće. Napredak, 140(4), 446-457.

Polić, M. (2005). Osobnost i dokolica. In M. Matijević (Ed.), Zbornik učiteljske akademije u Zagrebu (pp. 35-47). Učiteljska akademija.

Previšić, V. (1994). Multi - interkulturalizam kao odgojni pluralizam. In M. Matijević, M. Pranjić, \& V. Previšić (Eds.), Pluralizam u odgoju i školstvu (pp. 19-22). Katehetski selezijanski centar.

Reeh, U. (2008). Schulkunst. Kunst verändert Schule. Beltz Verlag.

Ritzer, G. (1997). Suvremena sociologijska teorija. Nakladni zavod Globus. 
Shields, R. (2001). Virtualni prostori, stvarne povijesti i živuća tijela. In R. Shields (Ed.), Kulture interneta (pp. 23-34). Naklada Jesenski Turk i Hrvatsko sociološko društvo.

Stoll, L., \& Fink, D. (2000). Mijenjajmo naše škole. Educa.

\author{
Jasenka Martinčević \\ Third Elementary Schol Varaždin \\ Trg Ivana Perkovca 35, 42000 Varaždin, Croatia \\ jasenka.martincevic@gmail.com
}




\section{Pedagoško osmišljavanje slobodnoga vremena učenika osnovne škole}

\section{Sažetak}

Cilj istraživanja bio je ispitati povezanost izmedu sociodemografskih karakteristika i procjene važnosti pojedinih sekundarnih potreba učenika od 5. do 8. razreda osnovne škole. Uzorak čini 196 ispitanika. Polazna osnova bio je koncept „četiri želje" za definiranje situacije, W. I. Thomasa (1863. - 1947.) Kao instrument za ovo istraživanje korišten je posebno konstruiran anketni upitnik, temeljen na Thomasove četiri želje: želja za sigurnošću, želja za suosjećanjem, želja za priznanjem i želja za novim iskustvom.

Primijenjen je Mann-Whitneyev U test, faktorska analiza, deskriptivna statistička obrada, linearna regresijska analiza, Kruskal Wallisov test $i$ korelacijska analiza. Rezultati istraživanja pokazuju statistički značajne razlike u procjenjivanju važnosti pojedine potrebe sobzirom na spol, odnosno dob ispitanika. Utvrđena je korelacijska povezanost izražavanja važnosti potrebe za sigurnošću s obzirom na dob te pozitivna korelacija između procjene potrebe za priznanjem i dobi ispitanika. Nadalje, utvrđena je povezanost dobi i izražavanja važnosti potrebe za doživljajem novoga iskustva kod ispitanika. Istraživanjem smo dokazali da bitno veću potrebu za priznanjem iskazuju ispitanici ženskoga spola.

Ključne riječi: odgoj za slobodno vrijeme; pedagoško osmišljavanje slobodnoga vremena; potrebe učenika

\section{Uvod}

Dvadesetprvo stoljeće donijelo je mnoge promjene u svakodnevni školski život. U vremenu u kojem ima sve manje uporišta i neupitnih autoriteta, škola se također mijenja. Živimo u vremenu nestabilnih orijentira, gdje više gotovo da i nema nedodirljivih vrijednosnih utemeljenja. Dominiraju vrijednosti sve izoliranijih pojedinaca koji su neprestano na mreži čije im virtualno okruženje nudi sve više elektroničkih prijatelja. Prije dvadesetak godina pojavio se internet koji svakim danom postaje lako dostupan sve većem dijelu čovječanstva. World Wide Web ili www - svjetska paučina ili kratko rečeno internet rezultat je rada vojne industrije, potomak ARPANET-a, vojne računalne mreže u Sjedinjenim Američkim Državama. Taj je sustav nakon prijelaza na civilnu sferu postao u vrlo kratkom vremenu iznimno popularan diljem čitavoga svijeta. Prostorno 
gledano, poruke koje potječu s istoga mjesta istovremeno se šire i utječu daleko izvan granica tradicionalnih „zajednica neposrednog kontakta i državno sankcioniranih javnih sfera koje na lokalnoj razini mogu ograničiti rasprave i cenzurirati teme pod prijetnjom lokalnih sankcija" (Shields, 2001, str. 28). Internet nam kao i mnogi drugi pronalasci modernoga doba donosi mnoštvo pozitivnih pomaka, ali i raznih oblika otuđenja. Omogućena je interakcija na daljinu uz negiranje fizičke nazočnosti. Jedna od negativnih strana leži u tome što postoji svakodnevna pojava da se realna stvarnost stavlja u drugi plan, iza privida koje prikazuju mediji. Mala se djeca, koja još „... ne razlikuju stvaran i medijski prikazivan život, rado utapaju u razigranim, privlačno obojenim slikama s televizijskih i računalnih ekrana." (Košir, Zgrabljić, i Ranfl, 1999, str. 27). Svakodnevna medijska izloženost ukazuje na potrebu razvoja medijske pismenosti, koja bi imala i ulogu razvijanja sposobnosti kritičnoga promatranja sadržaja koji se nude na medijskom tržištu. Dostupnost neadekvatnih sadržaja povećava mogućnost manipuliranja djecom i mladima, a „najagresivniji oblik manipulacije je na internetu. Sve učestalija su prikazivanja brutalnih scena nasilja, a sve postaje kao ritual uzbudljive zabave" (Miliša, Tolić, Vertovšek, 2009, str. 178). No unatoč svemu tome, ovakva dostupnost sadržaja igra veliku ulogu pri uspostavljanju demokratskoga društva. Britanski sociolog Antony Gidenns govori da živimo u jednom „oslobođenom svijetu” i da još nije postojala vremenska epoha u kojoj su nastupile u tako malom vremenskom intervalu tako drastične promjene (Hainschink i Stumpner, 2012). Informiranost unutar generacijskoga kruga višestruko se intenzivirala, mladi u samo jednom trenutku mogu saznati što se događa na drugom kraju svijeta. To može biti velika prednost odgoja suvremenoga doba prožetoga vrijednostima interkulturalizma kao „načela i prakse modernih i demokratskih društava u smislu međusobnog razumijevanja, dijaloga, poštovanja Drugoga i Stranoga, te vještine življenja u različitostima" (Previšić, 1994, str. 19) te predstavlja važan preduvjet za suzbijanje predrasuda o strancima (Held, 1990).

Za sporazumijevanje ljudi dvadesetprvog stoljeća nije dovoljno osigurati tehničke uvjete pomoću kojih je neprestano prisutan na mreži, jer „... komunikacija među ljudima ne ovisi o tehnologiji nego o njihovim psihološkim motivima i situaciji u kojoj se nalaze” (Miljković i Rijavec, 2002, str. 5). Današnji odgajatelj zato više nego ikada do sada ima odgovornost razvijati kod odgajanika ,prikladnost, učinkovitost i fleksibilnost komunikacijske spremnosti” (Fisher i Adams, 1994, str. 222).

Današnji je svijet „brz, složen, zbijen i nesiguran” (Hargreaves, prema Stoll i Fink, 2000, str. 21). Zahvaljujući odgoju kao temeljnoj kategoriji ljudske egzistencije čovjek ima sposobnost prenošenja humanih vrijednosti. Škola je obrazovna, ali i odgojna institucija. Uz obvezne odgojno-obrazovne aktivnosti škola ima važnu ulogu u odgoju za slobodno vrijeme učenika, pri čemu teži da slobodno vrijeme mladih naraštaja postane prilika za kreativno stvaranje i promišljanje o svijetu koji nas okružuje. Od moderne se školske ustanove očekuje da učenicima uz obrazovne sadržaje omogućuje i sveukupno pozitivno ozračje. 


\section{Škola kao čimbenik pedagoškoga osmišljavanja slobodnoga vremena}

Svaki učenik ima svoje posebnosti koje su određene genetskim nasljeđem, poviješću kulturne zajednice iz koje potječe, ali i svojom individualnom voljom. Stoga jednake školske situacije učenici različito doživljavaju. Jedan od čimbenika načina doživljavanja svakako je odgojni utjecaj dotičnoga kulturnog okružja jer „stvaranje značenja podrazumijeva situacijske susrete sa svijetom u njihovim primjerenim kulturnim kontekstima kako bi se znalo o čemu je riječ. Premda su značenja 'u glavi', korijene i važnost vuku iz kulture koja ih stvara." (Bruner, 1996, str. 19).

Sve popularnija holistička paradigma suprotstavlja se reduciranju čovjekova bića na samo jednu - racionalnu dimenziju. Njezini pobornici naglašavaju da je čovjek jedinstveno biće koje ima svoju tjelesnost kao bitnu dimenziju ljudske egzistencije. „Povijest pedagogije je i povijest nestanka tijela u pedagogiji... sa Sokratom počinje skretanje od tjelesnog $\mathrm{k}$ duhovnom... a napori usmjereni k reformi škole i obrazovanja uopće na pragu 21. stoljeća neće moći zaobići tematiziranje i fenomena tjelesnosti” (Palekčić, 1999, str. 452).

Iako se afirmira i holistička paradigma shvaćanja čovjeka, kognitivno područje još uvijek zauzima središnje mjesto u školskom životu. Racionalnost i analitičnost u školskoj su praksi poželjne osobine. Kada se govori o učeniku, u prvi se plan stavlja njegova sposobnost mišljenja, pamćenja i zaključivanja. Unatoč ovim trendovima ne smijemo zaboraviti da je čovjek biološko, tjelesno, emocionalno biće sa svim svojim mnogobrojnim kvalitetama. Potreba za kretanjem je univerzalna ljudska potreba koja je izražena već u vrlo male djece. Tako se dijete već u kolijevci pokreće te tako jača svoje tijelo. Prva godina života vrlo je burno razdoblje, dijete uči hodati, a kretanje mu omogućuje bolje upoznavanje svijeta koji ga okružuje. Igra je djetetova temeljna aktivnost i gotovo uvijek je povezana s pokretom. To može biti trčanje, skakanje, poskakivanje u ritmu raznih brojalica i sl. Što je dijete mlađe, njegovo se kretanje teže može sputavati društvenim normama. Dugotrajno sjedenje u školskoj klupi stoga nije prirodno stanje, pa si jedan dio učenika pomaže kod svladavanja određenih kognitivnih sadržaja tako da se ljulja na stolcu ili premješta školski pribor na klupi. Međutim, učitelji mahom zbog svoje neinformiranosti o najnovijim rezultatima znanstvenih istraživanja, nemirne učenike proglašavaju nediscipliniranima, neposlušnima i inatljivima.

$\mathrm{Na}$ važnost razvoja čovjekove tjelesne dimenzije, a s posebnim naglaskom na ples kao specifičan način izražaja pokretom ukazuju mnogi autori. Zvukovi su oduvijek poticali čovjeka na pokret kao snažno sredstvo izražavanja osjećaja. Pojedini učenici mogu se najbolje izraziti upravo pokretom, pa bi se stoga plesni izraz trebao uvrstiti u školske kurikule ravnopravno uz druge izvannastavne školske aktivnosti. Didaktičkometodički osmišljen ples je pedagoški koncept koji razvija različite kompetencije. Kroz ples se snažno razvija osjećaj vlastite tjelesnosti i svjesnosti svoga tijela, tzv. Körperbewusstsein (Bergman, 2006). Ples pomaže pri razvoju motoričke spretnosti i 
razvoju osjećajnosti u povezanosti s određenim intelektualnim operacijama. Učenicima kojima je dijagnosticiran poremećaj pažnje stručno vođeni ples može uvelike pomoći. Ovom se aktivnošću naime pospješuje sposobnost koncentracije te predstavlja jednu učinkovitu vježbu kognitivnoga područja učenikove ličnosti. Nadalje, ples pomaže i kod razvoja samopoštovanja u vidu stjecanja povjerenja u vlastite sposobnosti što se prenosi na sve druge životne aktivnosti (Bergmann, 2006). Plesne aktivnosti koje su organizirane s grupom učenika, uz sve ostalo, unapređuju i učenikove socijalne kompetencije. Primjerice učenici jedni drugima pomažu upamtiti pojedine plesne korake, pa tako kroz plesnu aktivnost učenik se ponaša „... obzirno (rücksicht) prema ostalima. Osim toga razvija se spremnost za pridržavanje dogovorenih pravila. Uz dugo i zamorno sjedenje u školskoj klupi tijekom redovite nastave ples za dijete predstavlja i ... sportski oporavak i opuštanje i igru... koji kod učenika razvija čak i osjećaj za vrijeme, jer kad ... dijete različite ritmove izučava, onda uči razlikovati vremenske odsječke i moći će kroz to razvijati pojam vremena" (Bergman, 2016, str. 14). Svjetski poznati plesač i plesni pedagog Rudolf Von Laban (Slovačka, 1879. - Velika Britanija, 1958.) autor je djela koje je namijenjeno u prvom redu plesnim pedagozima. To epohalno djelo zove se Moderni izražajni ples u odgoju (Der moderne Ausdrucktanz in der Erziehung). Von Laban temelji svoju teoriju plesa na četiri čimbenika pokreta: prostor, snaga, vrijeme i protočnost pokreta (Bewegungsfluss). Metoda plesa kojoj je postavio temelje ima tri glavne točke: pozornost, kontrola i analiza. Razvoj navedenih osobina kod učenika važno je za mnoge buduće životne situacije. Von Laban naglašava da plešući „uranjamo u proces akcije kretanja", za razliku od sporta, rada ili sličnih tjelesnih aktivnosti gdje je naša usredotočenost usmjerena na praktični rezultat aktivnosti. To znači da je ples aktivnost pokreta radi pokreta samoga. Stoga je ovdje jedini cilj razvijanje izražajnosti, a time i postaje umjetnički izražajni ples (Ausdrucktanz). Labanovu školu izražajnoga plesa nastavila je njegova učenica Mary Wigman (1886. - 1973.). Budući da ples nema nikakvu pragmatičnu funkciju osim iskaza estetske esencije ljepote, možemo ga dovesti u vezu s izvornim smislom odgoja i škole kao mjesta gdje je učenje oslobođeno prisile, što jest i izvorno značenje pojma skhole. Taj je termin označavao mjesto izvornoga humanističkoga razvoja u okviru slobodnoga vremena, odnosno prema nekim autorima čiste dokolice, što u ovom kontekstu nosi potpuno pozitivno značenje. „Dok je besposlica vrijeme u kojem je čovjek slobodan od posla ili rada kao prisilne djelatnosti, dokolica je naprotiv vrijeme u kojem je čovjek slobodan za neposredno djelatno ostvarenje, za igru, za stvaralaštvo..." (Polić, 2005, str. 35).

Glazba je u životu čovjeka oduvijek imala veliku važnost, njome se izražavaju široke lepeze emocionalnih stanja: od velike radosti pa sve do duboke tuge. $U$ današnje doba visoke tehnologijske razvijenosti koja nam je donijela velike mogućnosti reproduciranja glazbe kroz razne široko dostupne medije povećala se mogućnost praćenja glazbenih pravaca. Mladi se često identificiraju s popularnim glazbenicima postajući im fanovima. Osim odlazaka na koncerte, što im je često nedostupno, mladi prate najnovije trendove preko raznolikih mogućnosti interneta. Mnogobrojne televizijske emisije ili aktivnosti 
preko interneta omogućuju i izravne kontakte s popularnim glazbenicima, (Stars zum Anfassen, Heyer i Palentien, 2013, str. 77) ili čak priliku mladima da pokažu svoje talente. Pripadnost određenoj glazbenoj sceni može biti i način identifikacije s određenom grupom, što je mladima itekako potrebno u toj dobi. Također, to može biti i način na koje mladi izbjegavaju različite vrste nerazumijevanja socijalne sredine u kojoj žive. Uz slušanje određene vrste glazbe, neki od njih stvaraju i vlastite glazbene uratke koje je danas moguće vrlo jednostavno predstaviti široj publici, pri čemu važnu ulogu imaju usluge YouTubea ili Facebooka. Sve se to realizira ne samo preko zvučnoga prikaza, već i izrađujući raznovrsne slikovne materijale, najčešće takozvane spotove. Na taj se način može pobuditi interes, zaintrigirati glazbenu scenu za vlastito glazbeno stvaralaštvo. Sviranje i pjevanje u takvim neformalnih skupinama pruža vrijedno stvaralačko iskustvo, a razvija također socijalno i kooperativno učenje. Nova paradigma brze izmjenjivosti i u ovom segmentu dolazi do izražaja jer je upravo ova visoka mogućnost prezentacije svoje medijske ponude izvor brze izmjenjivosti popularnosti (schnellebig) (Heyer i Palentien, 2013). Pedagoško osmišljavanje slobodnoga vremena učenika osnovne škole treba uzeti u obzir mogućnosti novih tehnologijskih dostignuća i pružiti učenicima mogućnosti njihova svakodnevnoga korištenja.

Bez obzira u kojem se obliku ostvarivala, umjetnost zauzima vrlo važno mjesto za sveukupno zdravlje čovječanstva. Samo mali dio populacije nosi u sebi stvaralački potencijal i sposobnost posebne senzibilnosti umjetničkoga izražavanja. Da bi se on doista i mogao što potpunije razviti, potrebno je osim urođenoga dara osigurati i mnoge druge uvjete. Za početak, potrebno je prepoznati određeni talent, pa strpljivo i kontinuirano pružati povoljne uvjete za njegovo poticanje. Aktivnosti u smislu razvoja takvih potencijala istodobno su određene „tzv. subjektivnim faktorima (društveni položaj mladih i njihovih roditelja, obrazovanja, sposobnosti, stečene navike), ali i takozvanim objektivnim faktorima (kulturno nasljeđe uže i šire okolice, aktualna ponuda i dostupnost određenih sadržaja i slično)" (Ilišin, 2008, str. 271). Mogućnost umjetničkoga izražavanja dostupna je samo manjem dijelu populacije. Umjetnost nije svima dana na jednak način. Naime, umjetnici su osobe visokoga senzibiliteta $s$ velikim darom ekspresije. No, zanimanje za umjetnost ne postoji samo u njezinih stvaralaca, već je to pojava koja snažno dotiče emocionalnu dimenziju gotovo svake osobe svojom neobičnošću i velikom duhovnom snagom. Umjetnost prepoznaje jedino čovjek kao posebno biće na Zemlji, što je dokaz da je umjetnost dio našega humanoga i kulturnoga svijeta. Stoga je treba učiniti dostupnom što većem dijelu čovječanstva. Važno je naglasiti da se kroz svakodnevnu usmjerenost odgajanja mladih naraštaja u takvom humanističkom pravcu, navedena zamisao velikim dijelom može ostvarivati u školi u okviru zadaća estetskoga odgoja. Prostor ovakvoga odgojnog utjecaja ne bi trebalo ograničiti na izvannastavne aktivnosti unutar školskoga kurikula. On bi se trebao širiti na cjelokupnu odgojno-obrazovnu praksu školske ustanove, ali isto tako prenositi i izvan institucionalnih okvira kao vrelo razvoja humanizma u najširem smislu. Oslobađanju emocionalne napetosti može pomoći bavljenje svim vidovima 
umjetničkoga djelovanja pri čemu bi mogli dati svoj značajan doprinos i priznati umjetnici. Tako bi dali svoj obol ne samo estetskom dimenzioniranju svijeta oko sebe, već bi pridonijeli razvijanju komunikacije s mladim naraštajem. Tako je primjerice zanimljiva inicijativa Ute Reeh, opisana u knjizi Schulkunst - Kunst verändert Schule. Opisuje se snažna angažiranost likovnih umjetnika pri razvoju ovakvih nastojanja u školi Dieter-Forte-Gesamtschule u Düsseldorfu u Njemačkoj. Autorica Reeh naglašava $\mathrm{da}, \ldots$ školska umjetnost znači umrežavanje umjetničkoga razmišljanja i školske kulture" te da navedena inicijativa treba biti stalno utkana u bit škole kontinuirano, „... što je suprotno izoliranim vanjskim projektima.” (Reeh, 2008, str. 13). Učenici trebaju osjetiti školski prostor kao svoje emocionalno područje u koje mogu slobodno kreativno zahvaćati. Uređenje školskih prostorija, od učionica, blagovaonica, hodnika pa sve do sportskih dvorana pod umjetničkim vodstvom može se pretvoriti u zapažene kreativne projekte u kojima se mladima dopušta preuzimanje inicijative, a time i preuzimanje odgovornosti za ishode određene zamisli. Mladima se time daje povjerenje za promjenu svoga životnog prostora, što može postati važan čimbenik unapređivanja emocionalnoga zdravlja učenika. Ovakvim postupanjem učitelja i školske uprave poručuje se učenicima da se u njih doista vjeruje, što je značajan doprinos u građenju međugeneracijskoga razumijevanja. Također je važno da se u realizaciju školskih intervencija u prostor uključe učenici različite dobi kako bi se pospješilo kooperacijsko učenje, empatijski odnos na svim razinama te stremljenje $\mathrm{k}$ zajednički odabranim ciljevima. Da bi se to moglo ostvariti i kontinuirano razvijati, „školska umjetnost treba razumijevanje i potporu uprave škole i kolega da bi mogla djelovati paralelno s krutim školskim strukturama..." (Reeh, 2008, str. 12). Škola je mjesto ostvarivanja odgojno-obrazovne djelatnosti. Međutim, škola je istovremeno i ustanova u kojoj se primjenjuje sve zamršenija zakonska regulativa dotične državne zajednice. Stoga je potrebno kontinuirano uravnoteživati emocionalno i racionalno, odnosno podupirati stvaralački pozitivan mladenački neobuzdani duh s jedne strane, i administrativne propise koji se često doimaju kao prepreke kreativnosti, s druge strane odgojno-obrazovne svakodnevnice.

Unatoč mnogim znanstvenim dokazima koji govore u prilog potrebe posvećivanja veće pozornosti tjelesnom i emocionalnom segmentu učenikove osobnosti, $u$ školskoj se praksi pod izlikom nedostatka vremena zbog preopširnih nastavnih programa, elementarna ljudska tjelesnost i emocionalnost neopravdano stavljaju u drugi plan. Navedene situacije dovode do nezadovoljstva, osjećaja neispunjenosti, a u konačnici mogu rezultirati nesigurnošću pa čak i neurozama kod učenika. Navedeno nepovoljno školsko ozračje nikako ne pridonosi poboljšanju kvalitete pedagoškoga rada škole, jer „ne respektirajući unutarnje iskustvo i stavljajući naglasak na vanjski svijet, na objektivno znanje, informacije koje treba usvojiti, zapamtiti, reproducirati, prenaglašavamo racionalnu sferu ličnosti i zapostavljamo osjećaje, stavove i vrijednosti i time osiromašujemo odgojno-obrazovni proces" (Bratanić, 2002, str. 61). 
Slobodno vrijeme je specifičan prostor slobode odabira svakog pojedinca u kojem leže veliki potencijali individualnoga kreativnoga razvoja. To je prostor u kojem se postavljaju temelji za razvoj određenih vrijednosti koje mogu biti pozitivne, humane $i$ konstruktivne. Međutim, u takvom još neoblikovanom, neodređenom i nezauzetom prostoru mogu prevladati nepovoljna vrijednosna stremljenja. Za mladu senzibilnu osobu slobodno je vrijeme po prirodi stvari predodređeno za neobuzdana, nestrukturirana promišljanja, ali i konkretna činjenja. Takav je prostor stoga rezerviran i za različita eksperimentiranja koja su zapravo jako korisna kao vježbalište za mladoga čovjeka. Isprobavanje i pomicanje granica kao važan segment razvoja zrelosti doprinosi svakom učenju, a poglavito učenju socijalnih vještina. Učeniku je stoga potrebno pružati što više prilika za samostalno donošenje odluka kao vrlo vrijedan dio procesa njegova odrastanja. Ovaj se proces treba odvijati u povoljnom okruženju, jer „sigurno je da se djeca moraju usuditi, moraju se osloboditi, ali ne smije ih se izručiti onima koji danas za njima posežu" (Flitner, 2005, str. 81). Suočeni smo i s problemom raznih vrsta društveno neprihvatljivoga ponašanja, pa stoga škole osmišljavaju i provode mnoge preventivne programe kako bi doprinijele jačanju samosvijesti, samopouzdanja i samopoštovanja (Jull, 2001) i da bi mladi prihvatili sebe i sve svoje kvalitete. Učenici bi trebali naučiti slušati jedni druge, razvijati sposobnost empatije, međusobno komunicirati i stvarati nove vrijednosti. Ako bi se barem djelomično uspjelo u navedenom, to bi dovelo do smanjenja sve učestalije pojave dosade među djecom. Ovo se na prvi pogled čini neobično jer smo svjesni činjenice da su učenici opterećeni dnevnim rasporedom obveza. Neposredno nakon školskih obveza odlaze na izvanškolske aktivnosti, a kad dođe kraj radnoga tjedna obuzima ih dosada koja je povezana s nesposobnošću organizacije i osmišljavanja svojega slobodnog vremena. Učenici često nisu u stanju bez vanjskoga poticaja raznih profesionalnih animatora osmisliti svoje slobodno vrijeme, koje bi zapravo trebalo biti jedini prostor osobne slobode. Ako ih ne podržimo u stvaranju vlastitih ideja, „ne nauče li ... stvarati svoj vlastiti svijet mogu jedino proizvoditi i trošiti stvari na način koji im drugi odrede" (Polić, 2005, str. 43). U današnje vrijeme ima mnoštvo „ponuda”. Sadržaja dakle ima na pretek, ali iz toga nepreglednog mnoštva „ponuda” treba znati odabrati određenu kvalitetu, ali i količinu određenih sadržaja, odnosno treba steći i umijeće opuštanja. Treba znati i ne raditi ništa, nego samo maštati, sanjariti ili promišljati, sam sa sobom. Ovo umijeće opisuje se u jednom plemenskom običaju Indijanaca: „... tko ne želi kontaktirati s drugima, okrene se jednostavno k stijeni i nitko ga ne smeta. Na sličan način mogli bismo se i mi osloboditi banalnih razgovora o vremenu, koje ljudi vode samo zato jer misle da moraju govoriti" (Makarovič, 1972, str. 87). Čovjek je društveno biće, pa je još davno Aristotel isticao čovjekovu narav poznatim terminom zoonpolitikon. Stoga naš učenik uz sposobnost poniranja i upoznavanja samoga sebe, treba biti sposoban živjeti i u zajednici s drugima. Da bi mogao (pre)živjeti u sve zamršenijim društvenim uvjetima, čovjek jednostavno mora biti upućen na ljude oko sebe i tako biti spreman na međusobno pomaganje i podršku. Razvijanje kulture timskoga rada imperativ 
je današnjega doba. Tehnologijska složenost nadilazi mogućnosti i kratkoću našega pojedinačnoga životnoga vijeka. Slobodno vrijeme može biti prilika zajedničkoga ugodnog druženja u kojem se ispunjavaju najrazličitije učenikove potrebe.

Jedna od temeljnih potreba jest potreba za kretanjem koja je dugo vremena sustavno zanemarivana. Izgovora za to ima napretek, a najčešći je izgovor onaj o nedostatku vremena. Ova se temeljna potreba može ispuniti na različite načine, od organiziranih sportskih aktivnosti, plesa kao vrlo sofisticirane aktivnosti, pa sve do jednostavne nestrukturirane istraživačke šetnje grupe vršnjaka kojoj se također mogu vrlo snažno razvijati, kako socijalne vještine, tako i kultura timskoga rada u najširem smislu. Svaka škola razvija se u željenom pravcu koji treba biti definiran školskim razvojnim dokumentima. Tako primjerice, kao jedan od prioritetnih ciljeva može se odrediti i razvijanje sposobnosti timskoga rada učenika. Jedna od mjera za provođenje ovako postavljenoga strateškog cilja može biti ustanovljenje izvannastavnih aktivnosti ili pak planiranje raznih aktivnosti tijekom školske godine koje će pridonijeti ostvarenju ovoga cilja. Tako se mogu organizirati i planinarske grupe, plesne grupe ili pak primjerice grupe mladih biologa ili ekologa koji sustavno timski prate razvoj određene biološke pojave, mladih tehničara koji rade na izradi određenoga tehničkog rješenja, mladih informatičara koji zajednički izrađuju program kojim će riješiti postavljen zadatak i slično. Za razvijanje kulture timskoga rada u školskim uvjetima posebno mjesto imaju izvannastavne aktivnosti. Ondje prevladava opuštenija atmosfera u odnosu na nastavu, jer se „strah od škole uvijek svodi ili dovodi u vezu sa strahom od ispitivanja i ocjenjivanja" (Matijević, 2004, str. 31). Učitelj je ovdje zapravo koordinator koji pomaže u razvoju tima. Praćenje se može provoditi bilježenjem u ranije pripremljeni obrazac protokola sustavnoga promatranja, kao npr. „strpljivo i spretno pomaže drugima, idejama i prijedlozima potpomaže rad grupe, zna slušati i prihvaćati druge, spretno posreduje ako se jave sukobi i slično" (Klipert, 2001, str. 62).

\section{Metodologija}

\section{Cilj}

Polazna teorijska osnova u ovom istraživanju bio je Thomasov koncept o četiri želje za definiranje situacije. W. I. Thomas (1863. - 1947.) predstavnik je Čikaške škole. Najpoznatije mu je djelo Poljski seljak u Europi i Americi, koje zapravo predstavlja svojevrsnu prekretnicu u metodologiji društvenih znanosti. Temeljna Thomasova misao koja je odredila daljnji razvitak metodologije istraživanja društvenih pojava jest poznata sintagma koja glasi „Ako ljudi definiraju situaciju kao realnu, bit će realna po svojim konzekvencijama" (prema Ritzer, 1997, str. 48). Doživljavanje vanjskoga svijeta ovisi o pojedinoj osobi, što znači da određena situacija za jednu osobu može biti emocionalno i kognitivno izuzetno snažno definirana, dok na drugu, ne mora ostaviti gotovo nikakav dojam te prolazi pored nje gotovo neopaženo. Ono što se događa unutar ljudskoga bića, odnosno što odgovara doživljaju određene vanjske realnosti zapravo određuje ponašanje pojedinca na konkretni vanjski podražaj. Način doživljaja 
dotične situacije ne određuje samo konkretno trenutačno ponašanje pojedinca, već postaje značajan čimbenik za buduće doživljavanje vanjskoga svijeta. Thomas smatra da osoba doživljava svijet oko sebe na sebi svojstven način te se ponaša u suglasju s doživljajem stvarnosti prema svoje četiri temeljne želje. Prema Thomasovim konceptu one su sljedeće: želja za novim iskustvom, želja za sigurnošću, želja za suosjećanjem i želja za priznanjem.

Cilj je istražiti kako učenici osnovne škole procjenjuju važnost ispunjavanja potreba za novim iskustvom, za sigurnošću, za suosjećanjem i za priznanjem. Analiza rezultata mogla bi postati temeljno polazište pri pedagoškom osmišljavanju slobodnoga vremena učenika osnovne škole. Učenik bi time posredno postao aktivni sudionik koncipiranja aktivnosti slobodnoga vremena, odnosno subjekt u odgojno-obrazovnom procesu. Da bismo omogućili uvjete u kojima bi škola postala središnje mjesto kreativnoga susreta (Bratanić, 1993) učenika i učitelja, potrebno je uspostaviti dobru komunikaciju te ispitati temeljne interese učenika. Kao polazište ovoga empirijskoga istraživanja odabrali smo Thomasov teorijski konstrukt o četiri želje za definiranje situacije koji nam je poslužio prilikom operacionalizacije potreba učenika osnovne škole.

Postavljene su sljedeće hipoteze:

- Ne postoji statistički značajna razlika u procjeni Thomasova koncepta o četiri želje za definiranje situacije s obzirom na spol ispitanika.

- Ne postoji statistički značajna razlika u procjeni Thomasova koncepta o četiri želje za definiranje situacije s obzirom na razred ispitanika.

- Ne postoji statistički značajna razlika u odabiru četiri najpoželjnije slobodne aktivnosti s obzirom na razred ispitanika.

- Ne postoji statistički značajna razlika u odabiru četiri najpoželjnije slobodne aktivnosti s obzirom na spol ispitanika.

\section{Uzorak}

Ispitanici su u ovom istraživanju bili učenici i učenice $(\mathrm{N}=196)$ dviju varaždinskih osnovnih škola: II. osnovne škole i III. osnovne škole u Varaždinu. Varaždinska II. osnovna škola je škola u središtu grada, a III. osnovna škola Varaždin nalazi se na južnom dijelu grada Varaždina. Dio školskoga područja III. OŠ Varaždin je prigradsko naselje, pa jedna četvrtina učenika dolazi u školu školskim autobusom. U II. osnovnu školu upisuje se godišnje oko 800 učenika, dok III. osnovnu školu Varaždin pohađa 400 učenika. Uzorkom su bili obuhvaćeni učenici od petoga do osmoga razreda. U istraživanju (Tablica 1) sudjelovalo je 92 (4 7\%) dječaka i 104 (53 \%) djevojčica. S obzirom na razred koji pohađaju bilo je 65 učenika petoga razreda, 40 učenika šestoga razreda, 50 učenika sedmoga razreda i 41 učenik osmoga razreda. Struktura ispitanika po razredima s obzirom na spol bila je sljedeća: od ukupno 65 učenika petoga razreda 29 (45\%) je bilo dječaka i 36 (55\%) djevojčica. Što se tiče ispitanika koji pohađaju šesti razred 17 ili $43 \%$ bilo je dječaka dok je djevojčica bilo 23 ili izraženo u postotcima-58 \%. U istraživanju je sudjelovalo 50 učenika sedmoga razreda, od čega 
26 (52 \%) dječaka odnosno 24 djevojčice (48 \%). Od ukupno 41 ispitanika, učenika osmoga razreda koji su sudjelovali u istraživanju je bilo 20 dječaka (49 \%), odnosno 21 djevojčica (51\%).

Tablica 1.

\section{Instrument}

U istraživanju je korištena metoda ankete, a instrument je bio anketni upitnik izrađen za potrebe ovoga istraživanja. U uvodnom dijelu anketnoga upitnika ispitanicima je ukratko predstavljeno istraživanje, uz zamolbu za iskrenost pri odgovaranju na pitanja. Navelo se da je anketa anonimna te da je važno da odgovore na sva pitanja. Nakon toga u uvodnom dijelu slijedila su pitanja vezana uz demografska obilježja ispitanika: spol i razred koji pohađaju.

U prvom dijelu anketnoga upitnika navedeno je šesnaest tvrdnji, koje su ispitanici trebali procijeniti skalom procjene od pet stupnjeva, pri čemu je 1 značilo da se nimalo ne slažu s tvrdnjom, dok je 5 značilo da se potpuno slažu s tvrdnjom. Ispitanicima su dane detaljne upute o načinu ispunjavanja ovoga dijela upitnika. Ponuđeno im je šesnaest tvrdnji koje opisuju četiri Thomasove želje za definiranje situacije. Faktorskom analizom izlučena su četiri faktora koja odgovaraju Thomasovom konceptu.

F1 - Želja za sigurnošću operacionalizirana je kroz sljedeće tvrdnje: (12) U školi sam stekla/o svoja najbolja prijateljstva; (15) Mislim da je naša škola jedna od najboljih; (9) Imam prijatelja/prijateljicu u školi kojoj se mogu uvijek povjeriti; (16) Ponosim se što sam učenik naše škole; (7) Izvannastavne aktivnosti koje imamo u školi u potpunosti zadovoljavaju moje potrebe.

F2 - Želja za suosjećanjem operacionalizirana je kroz sljedeće tvrdnje: (14) Mislim da bi rezultate našega rada češće trebali vidjeti naši roditelji, prijatelji i svi drugi; (11) Trebali bismo više pomagati jedni drugima; (6) Najsretniji/a sam sa starim prijateljima.

F3 - Želja za priznanjem operacionalizirana je kroz sljedeće tvrdnje: (2) Odlazak na izlete u nepoznato nešto je najbolje; (5) Mislim da je doma ipak najbolje (utvrđena je negativna korelacija); (10) Mislim da u školi imamo premalo vremena za prijateljske razgovore; (13) Da sam najbolji sportaš/najbolja sportašica u školi, mislim da bi to trebali svi znati.

F4 - Želja za novim iskustvom operacionalizirana je kroz sljedeće tvrdnje: (8) Ne volim nikakva iznenađenja, bilo ugodna ili neugodna (utvrđena je negativna vrijednost korelacije); (1) Želio/željela bih upoznati nove prijatelje; (3) Želio/željela bih se orijentirati u novom prostoru; (4) Želio/željela bih probati nešto doista novo, primjerice baviti se padobranstvom.

Tablica 2.

Tablica 3.

Tablica 4. 
Kaiser-Meyer-Olkin (KMO) indeks je veći od 0,5 što je granica prihvatljivosti uzorka za faktorsku analizu, a isto pokazuje i Bartlettov statistički test značajnosti (Sig.) koji je bitno manji od 0,05 pa je i prema tome opravdana primjena faktorske analize. Isto tako je i korelacija između pojedinih faktora vrlo mala, što nam dodatno pokazuje da su pojedini faktori doista obuhvatili čestice koje su međusobno vrlo kompaktno povezane. To nam je još jedan pokazatelj primjenjivosti Thomasova koncepta četiriju želje.

$\mathrm{U}$ drugom dijelu upitnika ispitanicima je ponuđeno petnaest vrsta izvannastavnih aktivnosti od kojih su ispitanici trebali odabrati četiri kao najatraktivnije. Ponuđene su sljedeće aktivnosti: (a) rolanje na školskom igralištu, (b) planinarenje - odlazak na planinarske izlete, (c) ples, (d) folklor, (e) slušanje glazbe - maštanje, (f) crtanje, (g) susreti s likovnim umjetnicima, (h) izrada lutaka, (i) plivanje, (j) modeliranje - izrada predmeta od gline i sličnih materijala, $(\mathrm{k})$ organizacija i realizacija humanitarnih akcija, (l) igranje raznih igara, $\mathrm{u}$ dogovoru s voditeljem - od pantomime do graničara, (m) razni sportski susreti - npr. međurazredna prvenstva u raznim sportovima, (n) sudjelovanje na natjecanjima vezanim uz individualne javne nastupe, kao na primjer pjevanje, recitiranje, pričanje viceva i sl., (o) postavljanje izložaba učeničkih radova (odabiranje i postavljanje radova na panoe). Učenici su na kraju imali mogućnost i (p) dopisati aktivnost koja im se sviđa, a nema je na ovom popisu slobodnih aktivnosti.

\section{Rezultati}

Nakon provedenoga istraživanja došli smo do rezultata koji nam mogu pobliže opisati aspiracije učenika i učenica viših razreda osnovne škole. Ispitanici su procjenjivali šesnaest tvrdnji pomoću skale Likertova tipa od pet stupnjeva. Tvrdnje su se odnosile na različite aspekte promatranja školskoga života, ali i na životne aspiracije općenito. Primjerice, nekoliko tvrdnji opisivalo je različita viđenja sklapanja i održavanja prijateljstava u školi. Gotovo su svi ispitanici vrlo pozitivno procijenili tvrdnje vezane uz kvalitetu školskih prijateljstava. Tvrdnja koja glasi: (9) Imam prijateljicu/ prijatelja uškoli kojem se mogu uvijek povjeriti procijenjena je na skali od 5 stupnjeva prosječnom ocjenom 4,32, a tvrdnja (12) U školi sam stekao/stekla najbolja prijateljstva prosječnom ocjenom 4,25. Ispitanici uglavnom visokom ocjenom vrednuju sveukupna školska iskustva, što se može potkrijepiti i srednjom ocjenom tvrdnji koje glase: (16) Ponosim se što sam učenik svoje škole (prosječna ocjena je 4,57); (15) Mislim da je naša škola jedna od najboljih (prosječna ocjena je 4,03). Ispitanici su svjesni potrebe međusobnoga pomaganja i solidarnosti među učenicima. Stoga tvrdnju (11) Trebali bismo više pomagati jedni drugima procjenjuju vrlo visokom srednjom ocjenom 4,76. Rezultati procjenjivanja šesnaest tvrdnji prikazani su u Tablici 5.

Tablica 5.

Prikaz 1.

Pitanja (1) Želio/željela bih upoznati nove prijatelje i (11) Trebali bismo više pomagati jedni drugima imaju najmanju standardnu devijaciju, najmanje standardno odstupanje 
od prosjeka, oko 0,6, ujednačenija su od ostalih pitanja, slijede pitanja (6) Najsretnija/ ji sam sa svojim starim prijateljima i (16) Ponosim se što sam učenik/ca svoje škole sa vrijednostima oko 1, dok s druge strane pitanja (5) Mislim da je doma ipak najbolje, (7) Izvannastavne aktivnosti koje imamo u školi u potpunosti zadovoljavaju moje potrebe $\mathrm{i}$ (13) Da sam najbolji/a sportaš/ica u školi, mislim da bi to trebali svi znati imaju najveće odstupanje, oko 1,5 , najrazličitiji su odgovori. Ostala pitanja imaju dosta ujednačeno odstupanje.

Srednje vrijednosti odgovora na pitanje (8) Ne volim nikakva iznenađenja, bilo ugodna ili neugodna (vrijednost oko odgovora 2 ne slažem se) i (13) Da sam najbolji/a sportaš/ ica u školi, mislim da bi to trebali svi znati (vrijednost oko odgovora 3 neodlučan) bitno se razlikuju od srednjih vrijednosti odgovora na ostala pitanja koja se kreću oko odgovora 4 (slažem se) i 5 (u potpunosti se slažem).

Analizom šesnaest tvrdnji koje opisuju četiri Thomasove želje za definiranje situacije pokazalo se da su unutar šesnaest čestica najujednačenije rezultate donijeli rezultati dviju tvrdnja, što zaključujemo temeljem niske vrijednosti standardne devijacije kao mjere odstupanja. Naime, ove dvije tvrdnje vrlo slično procjenjuju ispitanici bez obzira jesu li ženskog ili muškoga spola. Tvrdnje koje glase (1) Želio/la bih upoznati nove prijatelje i (11) Trebali bismo više pomagati jedni drugima su tvrdnje kojima je srednja vrijednost vrlo visoka, iznosi kod djevojčica čak 4,81 , a kod dječaka 4,57 , što znači da je većina ispitanika odgovorila da se s navedenim tvrdnjama potpuno slaže. Navedeno govori u prilog da je odgojni utjecaj na mlade naraštaje ipak snažan, što se poglavito vidi u procjeni tvrdnje o međusobnom pomaganju. Također, učenici su otvoreni za nova iskustva i za upoznavanja novih osoba. Navedeno može biti ohrabrujući podatak koji svjedoči otvorenost mladih ljudi prema drugima. Isto tako, učenici pokazuju visok stupanj identifikacije sa svojom školom (16) bez obzira jesu li dječaci ili djevojčice, što pokazuju srednje vrijednosti za dječake 4,49, odnosno za djevojčice 4,63. Navedeno možemo protumačiti kao odraz vrlo pozitivnoga predznaka školskoga ozračja u kojem se učenici osjećaju ugodno i sigurno.

Mann-Whitneyevim U testom (Tablica 6) utvrdili smo da u većini slučajeva ne postoji statistički značajna razlika procjenjivanja navedenih tvrdnji, a što je donekle vidljivo i grafički iz prikaz 1. Međutim, tome nije tako u procjeni tvrdnje koja glasi (1) Želio/la bih upoznati nove prijatelje ( $\mathrm{p}=1,7 \%$ ). Dječaci procjenjuju (Tablica 5) želju za upoznavanjem novih prijatelja srednjom ocjenom 4,57, dok djevojčice tu želju procjenjuju ocjenom 4,81 . Utvrđena je statistički značajna razlika s obzirom na spol ispitanika (Tablica 6) i u procjenjivanju tvrdnje pod rednim brojem $15(\mathrm{p}=0,3 \%)$ koja se odnosi na procjenu škole kao jedne od najboljih. Dječaci procjenjuju svoju školu (Tablica 5) nižom srednjom vrijednošću, 3,73, u odnosu na djevojčice koje imaju pozitivnije mišljenje o školi koju pohađaju, što pokazuje i viša ocjena-4,29. Čini se da je škola ustanova koja je koncipirana tako da je pristupačnija djevojčicama u odnosu na dječake. Uočeno je da nema razlike u srednjim vrijednostima za dječake i djevojčice kod procjene tvrdnje koja glasi (12) Uškoli sam stekla/o svoja najbolja prijateljstva. To 
znači da svi učenici, bez obzira na spol, u školi doista stječu svoje prijatelje, a samim time i razvijaju socijalne kompetencije.

Tablica 6.

Tablica 7.

Tablica 8.

Iz Tablice 7 vidljivo je da postoji statistički značajna razlika u procjeni faktora Želja za novim iskustvom s obzirom jesu li ispitanici dječaci ili djevojčice ( $p=1,5 \% ;<5 \%)$. Također je utvrđena statistički značajna razlika u procjenjivanju faktora Želja za sigurnošću ( $\mathrm{p}=0,1 \%$ !), Želja za priznanjem ( $\mathrm{p}=0$ \% !) i Želja za novim iskustvom $(\mathrm{p}=3,7 \%)$ s obzirom na to koji razred ispitanici pohađaju. Dodatno je vidljivo i iz tablice 8 mala negativna korelacijska povezanost $(r=-0,28)$ izražavanja potrebe za sigurnošću kod ispitanika s obzirom na razred koji pohađaju. Što su učenici stariji, to manje pozornosti pridaju faktoru koji opisuje potrebu za sigurnošću prema Thomasovu konceptu. Ovaj rezultat zapravo ne čudi jer učenici sve više istražuju svoju okolinu i osamostaljuju se kako kreću u više razrede. Ovaj rezultat to i empirijski potvrđuje. Suprotne empirijske pokazatelje dobili smo analizom faktora koji izražava potrebu za priznanjem kod ispitanika. Utvrđena je doduše mala, ali ipak pozitivna korelacija $(r=0,28)$ između izražavanja potrebe za priznanjem i dobi ispitanika. Dakle, što su učenici stariji snažnije izražavaju svoju potrebu za priznanjem.

$\mathrm{U}$ drugom dijelu upitnika ispitanici su izražavali svoje preferencije prema izvannastavnim aktivnostima. Od ponuđenih sedam izvannastavnih aktivnosti trebali su odabrati četiri, kojima bi se željeli posvetiti u svoje slobodno vrijeme. Ispitanicima je dana uputa da odaberu četiri vrste izvannastavnih aktivnosti zbog kojih bi rado došli u školu, pa makar to bilo subotom koja je inače slobodan dan.

Kao što je vidljivo iz Tablice 9, dječacima od 5. do 8. razreda najprivlačnija je slobodna aktivnost pod nazivom Razni sportski susreti - npr. međurazredna prvenstva u raznim sportovima, dok je djevojčicama od 5. do 8. razreda najprivlačnija aktivnost Rolanje na školskom igralištu. Učenicima i učenicama petih i šestih razreda na prvom je mjestu aktivnost pod nazivom Planinarenje - odlazak na planinarske izlete. Učenice i učenici polaznici sedmoga i osmoga razreda najčešće biraju slobodnu aktivnost pod nazivom Razni sportski susreti - npr. medurazredna prvenstva u raznim sportovima.

Tablica 9.

Prikaz 2.

Prikaz 3.

\section{Rasprava i zaključak}

Ovo istraživanje pokazalo je kako učenici doživljavaju školski život. Došli smo do saznanja u kojem smjeru je potrebno razvijati školski kurikul kako bi se učenicima 
pružio odgoj za samostalno koncipiranje slobodnoga vremena kao značajnoga fenomena suvremenoga društva. Generalno, rezultati pokazuju da se u postojećem odgojno-obrazovnom sustavu djevojčice bolje osjećaju u odnosu na dječake. Ispitanici izražavaju da im nedostaju tjelesne aktivnosti, igra, natjecanja i zabava, pa bi u tom smislu trebalo usmjeravati osmišljavanje slobodnoga vremena u školskoj ustanovi.

Društvena okolina utječe na promjenu ponašanja učenika, ali i na to kako on doživljava svoju okolinu, kako je prerađuje te stvara svoj unutarnji duhovni svijet. Odgojni čimbenici zasigurno velikim dijelom određuju stremljenja, odnosno drukčije rečeno - aspiracije naših mladih naraštaja. Da bismo upoznali naše učenike, potrebno je razgovarati o njihovoj percepciji sreće u najširem smislu toga pojma, tj. saznati što oni žele postići u svom životu sada, u ovom trenutku. Koncepcija odgoja za neka daleka buduća vremena čini se nije više aktualna jer učenici se nalaze ovdje i sada s nama odraslima spremni za zajedničko mijenjanje životnih uvjeta. Otvoreni su prihvatiti naš odgojni utjecaj kao relevantan čimbenik, odnosno uzeti nas u obzir kao „Značajne druge” (Mead, 2003) od kojih ipak imaju što naučiti unatoč dostupnosti mnogobrojnih informacija. Svaka je osoba drugačija po svojoj naravi, pa tako rezultati ovoga istraživanja pokazuju da jedna grupa ispitanika preferira sigurnost i toplinu vlastitoga doma. Ova grupa ispitanika ne voli iznenađenja, nepoznate situacije niti promjene u najširem smislu. S druge strane su ispitanici koji su zainteresirani za nova iskustva i neprestano traženje novih doživljaja. Kakvi su naši ispitanici, što žele postići i zašto - to su pitanja na koja smo djelomično odgovorili ovim istraživanjem. Da bi se uspostavila i ojačala međugeneracijska solidarnost, potrebno je pokazati jasnu namjeru, inicijativu, spremnost i umijeće za upoznavanjem ispitanikova „referentnog okvira”. Izostanak spremnosti za razgovor dovodi do stanja bez komunikacije kakvoj težimo, pa će stoga jaz između generacija postajati sve izraženiji. Organizirajući slobodno vrijeme učenika u školi treba svakako uzeti u obzir njihove interese i želje jer to je prostor slobodnoga izbora u kojem se treba poštivati učenikova slobodna volja. 